\title{
Role of Indonesian Humanitarian Diplomacy toward Rohingya Crisis in Myanmar
}

\author{
Asep Setiawan ${ }^{1}$, Hamka $^{2}$ \\ \{asep.setiawan@umj.ac.id ${ }^{1}$,hamkaumj@gmail.com² ${ }^{2}$, \\ Universitas Muhammadiyah Jakarta, Indonesia ${ }^{1,2}$
}

\begin{abstract}
This study is aimed to analyze role of Indonesian humanitarian diplomacy toward Rohingya issue after crisis and violence in State Rakhine, Myanmar in 2017. A hundred thousand of Rohingya ethnic were forced to become refugee in Bangladesh border. Indonesian humanitarian diplomacy was conducted during the crisis when the world put high attention on the Rohingya's plight. The study uses qualitative method with a case study approach. The study found that Indonesian humanitarian diplomacy toward Rohingya plight in Myanmar was conducted as a part of foreign policy implementation to become proactive policy in maintaining order and peace in the world, including Southeast Asia region. In addition, role of humanitarian diplomacy is to help Rohingya escape from violence and helping refugee. Last finding, the humanitarian diplomacy is also as a bridge to offer political solution without intervention on Myanmar domestic affairs even though Naypyidaw's government did not fully welcome on Jakarta's proposal.
\end{abstract}

Keywords: Myanmar, Rohingya, Rakhine, Indonesia, Diplomacy, Humanitarian.

\section{Introduction}

The humanitarian crisis in Myanmar's Rakhine state in 2017 has sparked worldwide attention. The victims fell on the Rohingya ethnic side because of the reported violence committed by Myanmar's military units. The violence according to the United Nations has claimed the lives of hundreds of people from the Rohingya ethnic group. Most of the Rohingyas affected by violence fled to the Bangladesh border. Records as of February 2018 stated that 700,000 Burmese from the Rohingya ethnic group fled their homeland to a refugee camp on the Bangladesh border.

The humanitarian tragedy that occurred in 2017 is like repeating what happened in 2012. Increased conflict in 2012 between Myanmar ethnic and Rohingya in the state of Rakhine began with the rape, robbery and murder of a Rakhine woman by three Muslim young men in Yanbe city May 28, 2012. Then continued with the killing of ten Muslims men on a bus in the city of Taun on 3 June 2017. After these two incidents, riots erupted between two communities in three cities namely Sittwe, Maungdaw and Buthidaung.

The Myanmar government said in its July 2017 report that 77 people were killed from both communities and 109 were injured, 4822 houses, 17 mosques and 15 temples and three schools were burned down. The Myanmar government then revised the number of victims on 21 August 2017 which mentioned that 88 people were killed, 31 Rakhine and 57 Rohingya [1]. But the Equal Rights Trust (ERT) in a June 2017 report, which quoted Tun Khin of the Burmese 
Rohingya Organization in the United Kingdom (BROUK) that 650 Rohingyas were killed by government and ethnic Rakhine soldiers and at least 1200 missing.

The world responded to the human tragedy by strongly criticizing the Myanmar government which is still dominated by the military. Even Nobel Prize Laureate Aung San Suu Kyi was criticized for allowing violence against ethnic Rohingya. Unlike the world which only strongly condemns the Myanmar government and calls for a boycott of Myanmar and there is even a demand for intervention in Myanmar, Indonesia conducted humanitarian diplomacy against its neighbor. Indonesian diplomacy is carried out through, among others, sending humanitarian aid directly to areas affected by the humanitarian crisis.

This rapid response from Indonesia was carried out to pay attention to the fate of the refugees who needed food and medical assistance and shelter. Indonesia chose to help refugees flooding in Bangladesh and part of those affected in the Rakhine region in Myanmar. The move was taken to focus on the fate of the oppressed Rohingyas.

Indonesia did not choose Myanmar's internal affairs to resolve the Rohingya's conflict even though Jakarta has this capability. But Indonesian government in dealing with the tragedy deploys diplomacy by providing humanitarian assistance. With this motive for humanitarian assistance, Foreign Minister Retno Marsudi was accepted by Myanmar's authorities for the first time since the tragedy resurfaced in 2017.

Foreign Minister Retno Marsudi paid a visit to Myanmar to provide assistance to victims of the riots in the Sitte region, Rakhine State. The Indonesian Foreign Minister was the first Foreign Minister in ASEAN who was given access by the Myanmar government to visit the interior of Rakhine State after the riots on 12 October 2017.

Indonesia does not only stop at the stage of humanitarian diplomacy but also offers a comprehensive solution to the Rohingya issue. Foreign Minister Retno conveyed Indonesia's proposal called Formula 4+1, which is four main elements that must be done immediately so that the humanitarian and security crisis in Rakhine State does not worsen, plus one element of the immediate implementation of the recommendations of the Advisory Commission Report for Rakhine State led by Kofi Annan [2]. This formula makes humanitarian diplomacy has a fairly comprehensive framework.

With the urgency of the situation that be felt the Rohingyas in Indonesia itself, there has been an insistence that the government act harshly against Myanmar's rulers for being accused of allowing violence by the military against the Rohingyas. Public protests that expressed concern over the fate of the Rohingya ethnic group emerged in Indonesia. Even the Myanmar Embassy building in Jakarta became target of the anger of Indonesian citizens who are sympathetic to the fate of the Rohingya ethnic group who embraced Islam in the middle of the majority ethnic Myanmar who are Buddhist. This religious sentiment emerged in Indonesia to pressure the government in Jakarta to take action against the Myanmar government. Various demands arose from the community besides raising funds to send aid to Myanmar.

The 2017 tragedy is indeed very hard for Rohingya because it has never found a solution since the door to political reform in Myanmar began. Based on the latest data reported by the AFP news agency February 6, 2018 it appears that the number of refugees is still high. 


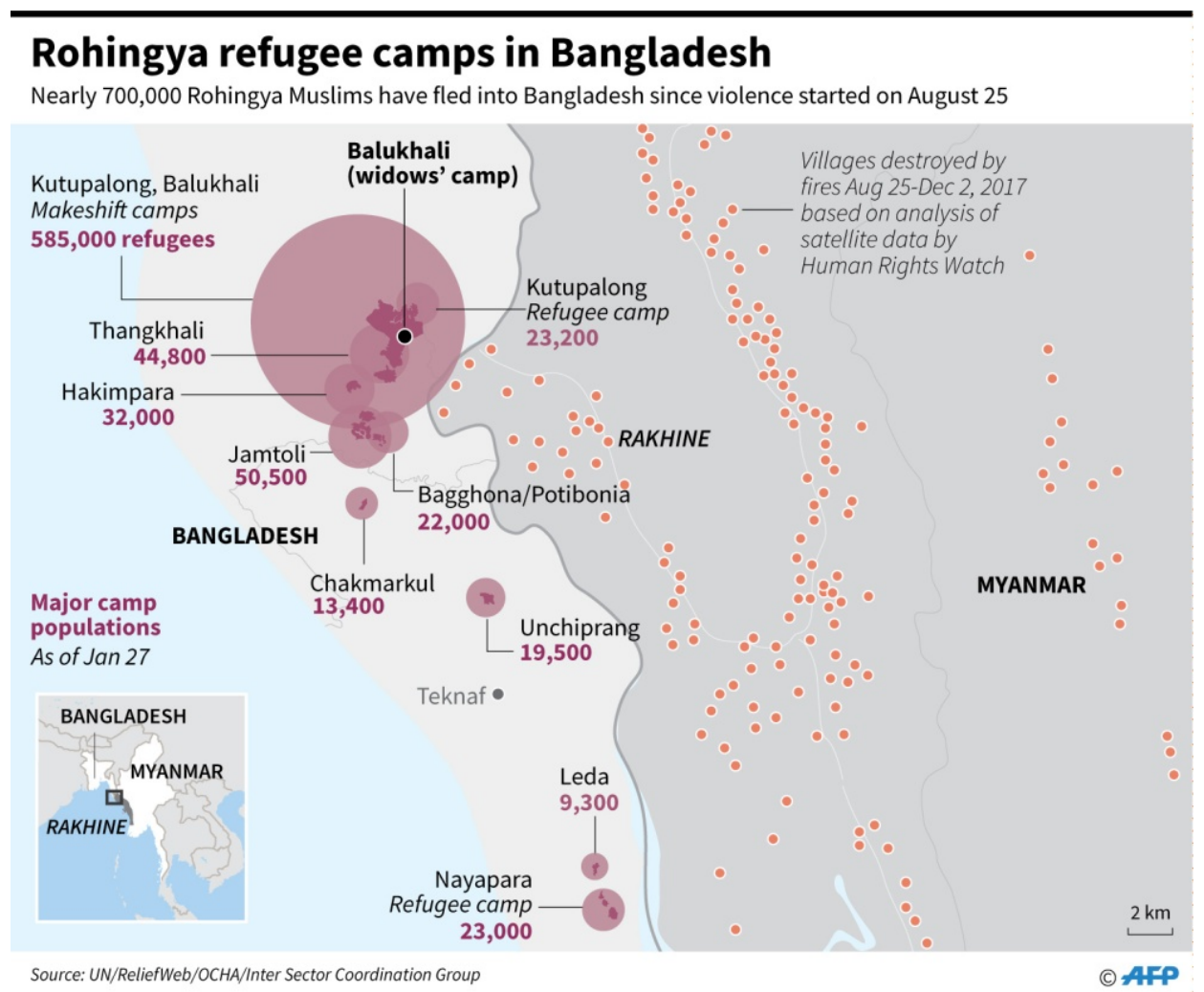

Fig. 1. Rohingya Refugees (AFP News Agency, 6/2/2018).

A number of studies have been carried out to analyze how Indonesia faced the crisis in this neighboring country. Santyabudi, for example conducted a study of Indonesian foreign policy in providing humanitarian assistance to Rohingya in 2017 by delivering the share ideas both internal and international. The majority Muslim factor, the existence of religious institutions, community protest actions are some of the domestic factors why Indonesia helps the Rohingya. While international factors like Turkish assistance, UN Resolution and Rohingya conditions in Myanmar are driving the delivery of Indonesian aid to the country.

Another study was conducted by Anggorono who discussed Indonesia's foreign policy analysis in dealing with Rohingya refugees. By using the concept of two-level games, this study found that humanitarian assistance to the Rohingya ethnic group in the form of refugee shelter has domestic and international dimensions. The study of Rohingya refugees was also carried out by Silvya, Hidayat and Pratisti who concluded that humanitarian reasons were one of Indonesia's driving forces to accommodate Rohingya refugees in Aceh. In addition, Indonesia realizes that the need for solutions to the Rohingya problem in Myanmar is carried out through bilateral diplomacy and ASEAN organizations.

While Ardani in her study explained that the character of President Susilo Bambang Yudhoyono helped Indonesian involvement in solving the Rohingya problem in Myanmar [3]. Jati described a comparative study of ASEAN and the Organization of Islamic Cooperation (OIC) in responding to spiritual crisis in Myanmar [4]. According to Jati, ASEAN has limitations in responding to the Rohingya crisis in Myanmar. The OIC can carry out bilateral 
and multilateral responses. In addition, ASEAN responded to the crisis through a consensus mechanism. Whereas the OIC in the decision-making mechanism can be carried out with the approval of two-thirds of the members. ASEAN is also bound by the consensus mechanism and the principle of non-intervention to its members.

Indonesia's involvement in assisting the peace process in Myanmar was apparent when Jusuf Kalla as chairman of the Indonesian Red Cross shared his experiences in resolving conflict problems in Aceh. Kalla mentioned by Lina A. Alexandra, that PMI wanted to remain in Rakhine State for the post-conflict rebuilding program in 2012 [5]. Therefore, puzzle for the research is why Indonesia choose humanitarian diplomacy to deal with the Rohingya crisis and what the role of Indonesian diplomacy is in 2017.

\section{Literature Review}

To understand how humanitarian diplomacy toward Myanmar in time of Rohingya crisis, a number of concepts will be explored, firstly relate to diplomacy including humanitarian diplomacy. In further explore is what humanitarian crisis context of international relations. According to K.J. Holsti diplomacy is one of element of foreign policy [6]. Others instrument in foreign policy are propaganda, economic aid, military intervention and war. Diplomacy is conducted by communication via representative officials that send to other countries or organizations who are called diplomats. Therefore, Holsti mentions that foreign policy is an idea or an action who made by foreign policy maker to resolve an issue or making changes in a policy, attitude or action of a country in non-state actors, international economy or physical environment [6].

Holsti's meaning on foreign policy is supported by James Rosenau that states there are three conceptions on foreign policy "as cluster of orientations, as a set of communication to and plans for action and as a form of behavior" [7]. As cluster orientations, a foreign policy refers to a tendency and principles for state behavior in international affairs. As a set of communication to and plans for action the concept means where a country connects itself to the external environment in concrete plans and commitments to promote and protect itself overseas in accordance with the country's basic orientation.

This concept is often referred to as strategy, decision or policy. While the third understanding of foreign policy as an activity that translates orientation and development and articulation of specific goals and commitments. This concept makes foreign policy a behavior to the external environment of a country.

Regarding diplomacy itself has various meaning. According to Satow (1917) as quoted by Devetak, Diplomacy is the application of intelligence and tact to the conduct of official relations between the governments of independent states, extending sometimes also to their relations with vassals states; or more briefly still, the conduct of business between states by peaceful means [8].

What is meant by diplomacy is the use of intelligence and wisdom to conduct official relations between the governments of independent countries. Sometimes it is also carried out in the relations of the countries of followers or, more briefly, the implementation of such affairs is carried out between countries in a peaceful manner.

According to Nicholson diplomacy is the management of international relations by negotiations; the method by which these relations are adjusted and managed by ambassadors and envoys; the business or art of the diplomatist [8]. In addition, Brownlie states that diplomacy 
is every means taken to establish and foster relationships and communicate with each other or carry out political or legal transactions which in every case are carried out through authorized representatives.

Other meaning of diplomacy is described by Berridge (2015) as an essentially political activity and, well resourced and skillful, a major ingredient of power. Its chief purpose is to enable states to secure the objectives of their foreign policies without resort to force, propaganda, or law. It achieves this mainly by communication between professional diplomatic agents and other officials designed to secure agreements [9]. In addition Holmes and Rofe (2016) state that diplomacy is the 'art' of politics or the leadership of a country and the conduct of public or foreign affairs [10].

From various diplomacy meaning, it is clear that one country carries out policies to other countries based on the national interests that it has formulated. The procedure for diplomacy to other countries has been regulated in international law called the Vienna Convention. This means that when dealing with other countries there are international norms where relations cannot be done without the approval of the destination country and also carried out in a friendly manner. But when state relations are deteriorating, diplomacy will also not work as it should. What is clear as said by K.J Holsti that the goal of foreign policy itself is to return to what is referred to as the general goal of the formation of a country namely security, autonomy (sovereignty), welfare and status and prestige [6].

\subsection{Humanitarian Diplomacy}

One type of diplomacy that arises because of ethical motives and international solidarity, a country can provide assistance to other countries affected by disasters or conflict. This diplomacy is known as humanitarian diplomacy. There are various understandings of what is called humanitarian diplomacy.

According to the study of the International Federation of Red Cross and Red Crescent Societies (IFRC) there are 89 types of understanding of humanitarian diplomacy. Much of that understanding concerns diplomacy by humanitarian aid organizations such as the International Community of the Red Cross (ICRC). While eight of them show that the state and non-state actors as humanitarian diplomacy.

Lamb defines humanitarian diplomacy as "maximizing support for operations and programs, and building partnerships necessary if humanitarian objectives are to be achieved" [11]. Harroff-Tavel gives meaning what humanitarian diplomacy means as developing a network of close bilateral or multilateral, official or informal relations with the protagonists of armed conflicts and disturbances, and with any other State, non-State actor or influential agent, in order to foster heightened awareness of the plight of victims of armed conflicts, support for the ICRC's humanitarian action and respect for humanitarian law.

In addition, Reigner describes "the term [humanitarian diplomacy] is used not only by humanitarian organizations but also by national co-operation agencies and ministries (foreign affairs, defense, development, civil protection) comprising humanitarian aid departments to respond to domestic or international emergencies" [12]. In this view humanitarian diplomacy is used as a tool for "raising awareness, negotiating, and mobilizing appropriate humanitarian aid in emergencies" by humanitarian organizations, states and the private sector.

According to the International Red Cross and the Red Crescent, Humanitarian diplomacy is a matter of decision makers and opinion leaders to act, at all times, in the interests of vulnerable people, and with full respect for fundamental humanitarian principles. This can be 
understood in the context that the organization helps in an atmosphere of peace, natural disasters and rescue operations [13].

The definition of humanitarian diplomacy interpreted by the International Red Cross is also described as a strategy for influencing the parties to armed conflicts and others-States, nonState actors and members of civil society. Its purpose is purely humanitarian and it is carried out through a network of sustained relationships-bilateral and multilateral, official and informal.'

An important and difficult part of humanitarian diplomacy is humanitarian negotiations with armed groups. That is why the UN defines it as humanitarian negotiations are "those negotiations undertaken by civilians engaged in managing, coordinating and providing humanitarian assistance and protection for the purposes of: (i) ensuring the provision of protection and humanitarian assistance to vulnerable populations; (ii) preserving humanitarian space; and (iii) promoting better respect for international law".

Humanitarian diplomacy elements that emerged from the understanding put forward by the International Red Cross were agreed to be humanity, impartiality, neutrality, independence, voluntary service, unity, and universality. With this understanding then in this diplomacy what will be called "Actively building and cultivating good relations and consent as part of a security management strategy with local communities, parties to the conflict, and other relevant stakeholders and obtaining their acceptance and consent for the humanitarian organization's presence and its work".

Humanitarian crises are occurred because of natural or human causes [14]. Natural-caused crises such as volcanoes, floods, tsunamis or earthquakes. Humanitarian crises arise along with the many falling human victims. Humanitarian crises can also be caused by human actions themselves such as conflict, war and famine. Conflicts can be emerged due to power struggles or they can be related to the struggle over natural resources.

In a number of conflict cases in various countries, ethnic conflict is one of the characters that often emerges. This ethnic conflict can cause large casualties among citizens because helpless civilians often become victims. Rohingya ethnic minorities in Myanmar are among the ones where ethnic conflict caused massive casualties and displacement.

Disasters and conflicts and the responses that trigger them are social phenomena. Natural disasters generate social vulnerability and trigger various responses from the public, bureaucrats, politicians and disaster management workers. Conflict is not only the result of social processes. Conflict penetrates into society where the causes and forms of conflict change and where conflict becomes a practice that can be learned like any other social practice. The intervention tried to change society but various people discussed the meaning and effect of the intervention.

\section{Research Method}

The research on Indonesia's humanitarian diplomacy towards Myanmar uses a qualitative approach. Qualitative research in this study is defined as research that intends to understand phenomena about what is experienced by research subjects such as behavior, perception, action holistically, and by means of descriptions in the form of words and language, in a special natural context and by utilizing various scientific methods [15]. Data collection for research is carried out through literature study. The research is also combined literature studies with interviews 
with government officials and academics related to foreign policy. The data analysis technique was conducted using qualitative data analysis methods.

\section{Finding and Discussion}

This part examines the role of Indonesian diplomacy in dealing with the crisis in Rohingya, Myanmar, where there were huge Rohingya casualties accompanied by a wave of refugees to the Bangladesh border. The main role played by Indonesia through humanitarian diplomacy is the implementation of the mandate of the Indonesian constitution to help create a peace in the world, another role for humanitarian diplomacy as soft diplomacy to help humanitarian crises and humanitarian diplomacy along with efforts to political solutions to crises in Rakhine State where ethnic Rohingyas live.

Indonesia's pro-active involvement through diplomacy instruments in resolving the Rohingya problem has its roots in Indonesia's international position. The constitutional mandate states that Indonesia actively participates in maintaining world order with the sound of the constitution "... follows the world order based on independence, eternal peace and social justice ..." In this context, the resolution of the crisis in Rohingya to participate in preventing the Rohingya ethnic tragedy in Myanmar has become a source of instability in the Southeast Asian region. There are even fears that the Rohingya militant group in Rakhine State could become a fertile ground for the growth of radical groups as happened in the southern Philippines.

In other words, Indonesia's humanitarian diplomacy on the Rohingya issue is driven by the basic principles of foreign policy that prioritize peace in the world, including in Southeast Asia. With this foreign policy principle, the Indonesian government is active in resolving the Rohingya case, including in providing humanitarian assistance and will be discussed later in the search for political solutions because it is not only Myanmar that is the problem but it is already in Southeast Asia and even Bangladesh.

Once again it can be emphasized that Indonesia's humanitarian diplomacy towards Rohingya is a policy based on values in the most basic foreign policy and mandated by the Preamble of the 1945 Constitution "to participate in carrying out world order based on freedom, eternal peace and social justice". Thus, it is clear that the steps taken in resolving these neighboring problems are based on efforts to maintain the stability of the Southeast Asian region that is needed by Indonesia. Indonesia does not want the resolution of the Rohingya issue by blaming the central government in Naypidau but also trying to build a bridge of good communication so that it can share views to give birth to the right policies with aspirations in Myanmar's central government.

Diplomacy on regional issues in Southeast Asia is included in the priorities within the framework of Indonesia's foreign policy. Addressing these issues around Southeast Asia can be understood in the context of this region is the closest concentric circle in Indonesia's foreign policy.

The Rohingya issue is actually an old issue that sometimes draws international attention and most of it is not so noticed. International attention to the Rohingya ethnic issue is getting stronger when Myanmar accepts a political system that is more open to people's participation. The military dictatorship was reduced and replaced by a government which was also filled by civilian officials despite the stronger military influence. Both active and retired military participated in managing the new government. They are united in the new government so that it is still a strong military element in the Myanmar government. 
Indonesia has a very clear policy towards the Southeast Asian region. This region is a pillar of national development so it is required that Southeast Asia be in a safe condition, free from conflicts between countries, free of conflicts within ASEAN members and also free from acts of terrorism. Because of Indonesia's policy of maintaining this region which is safeguarded, any incidents and conflicts that will destabilize the region will be taken seriously.

From this geographical and structural framework, Indonesia pays attention to the issues of Southeast Asia in this matter which emerged in Myanmar is a multidimensional Rohingya crisis. Rohingya issue cannot be seen only in terms of the majority of Rohingya ethnicity but also its status which is called stateless, discrimination and also violations of human rights that are sustainable. The fate of the Rohingya in an increasingly open world is becoming the world's attention coupled with cases of violence that have been popping up in the eyes of the world especially since 2012 and culminating among others in 2017.

When this issue emerged that strengthened since 2012, then Indonesia was called because one of Indonesia's foreign policy mandates referred to the mandate that Indonesia should participate in maintaining world order and peace. The basis of Indonesian policy continues to refer to the orientation of Indonesian policy that promotes peace. However, because in ASEAN there is a code of ethics that does not interfere with the internal affairs of a country, there is a limitation in helping Rohingya ethnic.

The Rohingya crisis if examined deeper has been going on for decades and without resolution. First, because this issue is a domestic problem in Myanmar and when Myanmar under the military junta is relatively unable to touch this sensitive issue so it does not emerge. Second, the issue of ethnic discrimination even in the next stage referred to as ethnic genocide is a principle that contradicts the objectives and practices of Indonesia's foreign policy. Third, as a neighboring country that runs a policy of discrimination against one ethnic group, Indonesia has a strong calling because of its experiences in Aceh and even in Papua. Ethnic differences have sparked conflict and even lasted dozens of years because there was no common ground in resolving this ethnic issue.

With this background, Indonesia's humanitarian diplomacy is framed in the ideals of Indonesia's foreign policy, which is to create world peace. In this case, it helps create peace in the Southeast Asian region which is very close to the Indonesian region. The conflict in Myanmar, even though its scale only concerns ethnic and religious differences, has caused a humanitarian crisis that has even been felt for a long time in Indonesia.

Myanmar Rohingya refugees came to Indonesia to seek asylum because of the oppression that occurred in their country. In Aceh, for example, there are already hundreds of Rohingya refugee in several camps. Not only in Aceh, some even crossed into Sulawesi and some approached the UNHCR office in Jakarta in an effort to find shelter in a third country. The increasing number of refugees pushed the Rohingya issue into a regional issue and caused regional problems where not only Indonesia was affected by the crisis but also countries around Myanmar such as Malaysia.

In contrast to Indonesia, which applied softly and showed an attitude of understanding this issue in its diplomacy, Malaysia immediately condemned the behavior of the military junta and the Myanmar government which did not handle the Rohingya ethnic groups in accordance with humanitarian principles. Dr Ryantori from the University Moestopo (Beragama) added that Malaysia had previously adopted a repressive foreign policy for what Myanmar was doing to the Rohingya ethnic group. The policy makes relations between the two countries become "uneasy". The government in Kuala Lumpur openly criticized the discriminatory policies of Naypyidaw's government which allowed thousands of people even hundreds of thousands to 
suffer from Buddhist militant and military pressure. Malaysia firmly states that this issue must be brought to the UN because of human rights violations in Myanmar.

In the next part, it was discussed that Indonesia's humanitarian diplomacy towards the Rohingya humanitarian crisis in the state of Rakhine played a role to focus on alleviating the ethnic burden of persecuted while also playing a role in encouraging public participation in alleviating Rohingya suffering due to the background of religious equality namely Islam. The issue of Islamic identity is also important in Indonesian humanitarian diplomacy so that various steps emerge that involve community groups who help in the form of finance and construction of places of worship.

Indonesia's policies in helping the Rohingya ethnic occur in 2017, thus it can also be studied how the policies of Jokowi's administration towards the Southeast Asian region. The Jokowi's government policy is reflected in a document called the 2015-2019 Strategic Plan. The Southeast Asian region is mentioned as the closest concentric circle in Indonesian foreign policy, so it needs to be a policy focus. The policy to protect the condition of Southeast Asia is to strengthen ASEAN.

By supporting ASEAN totally, Indonesia's policy towards Southeast Asia is also maintained. Through ASEAN, Indonesia has wider opportunities to coordinate its policies so that it has diplomatic power. Compared to the model of bilateral cooperation with nine countries in Southeast Asia, the framework for maintaining political stability and security in Southeast Asia is easier and more sustainable than bilateral cooperation.

In ASEAN, Indonesia has established itself as a "leader" so that it can provide guidance on where ASEAN is going and what policies should also not be carried out in accordance with the ASEAN Treaty Amity and Cooperation (TAC), friendship between its members. One of the guidelines in ASEAN is not to interfere in the domestic political affairs of its members. This is what gives ASEAN the strength of solidarity so that Indonesia is able to maintain the code of ethics of the behavior of its members when there are internal problems caused by separatists, ethnic conflicts or other political conflicts.

For this reason, Indonesia carried out humanitarian diplomacy in Myanmar. Indonesia involved ASEAN in distributing humanitarian aid in Rakhine State on the grounds that Myanmar is a member of ASEAN. Thus, the worsening situation in Rakhine needs to be helped without having to involve themselves in the internal problems of the members of the regional association.

In a number of statements issued by Indonesian Ministry of Foreign Affairs it appears that humanitarian issues are a priority in responding to the tragedy in the Rakhine state. Indonesia's policy in providing humanitarian assistance is prioritizing Rohingya ethnic group who are victims of violence rather than other ethnic groups in Myanmar. Foreign Minister Retno Marsudi said the focus of Indonesia's attention was the humanitarian crisis in Rakhine state.

This is one of the characteristics of Indonesia's foreign policy in handling the Rohingya case by giving priority to what can be called humanitarian diplomacy which is totally focused on alleviating the suffering of victims of violence, victims of oppression and victims of discrimination whether killed or expelled. The policy is reflected in the $4+1$ formula from Indonesia. By encouraging a focus on the facts on the ground that hundreds of thousands of refugees and hundreds of people were killed, Indonesia played a role in helping neighboring Myanmar without being negative about the cause of the refugee case.

Foreign Minister Retno said "We talked rather long about accessing humanitarian assistance to people who really need it. This humanitarian assistance mission will be led by the Myanmar government and involve the international community, in this case the ICRC and several other countries. Upon the proposal of Indonesia, the Myanmar government welcomed 
that Indonesia or ASEAN became an important part in the mechanism of providing humanitarian assistance in Rakhine State. The assessment regarding what assistance is given, which targets should take precedence will be immediately delivered".

Indonesian diplomacy that occurred in 2017 when the peak of the Rohingya crisis in Myanmar occurred focused on handling victims mainly from the Rohingya ethnic group. They became victims of violence because of the actions of security forces and militant groups with a Buddhist background. Some of these victims died and some were forced to flee to the border between Myanmar and Bangladesh. In fact, most of them live in refugee camps in Bangladesh.

Indonesia's attitude towards the Rohingya crisis can be understand from the statement of Foreign Minister Retno Marsudi "Indonesia did not choose to sit tight and shout, but instead used its diplomacy [in Rakhine State] with the purpose of helping all the victims and prevent the situation from escalating further".

From the statement of Retno Marsudi, it can be seen that Indonesia's policy towards the Rohingya crisis was conducted firstly by helping all victims of violence in Rakhine State. Second, it prevents the situation from getting worse because of the actions and reactions in the state of Rakhine which affected the Bangladesh border where hundreds of thousands of refugees could not be resolved even until 2019.

These two basic principles can be referred to as Indonesia's good intentions toward Myanmar in the face of a recent humanitarian crisis. Preventing more violence in the state of Rakhine as a result of acts of violence from a group of Rohinya militants believed to be an excess of radicalization in some separatist groups led to Myanmar's military crackdown. As a result, civil society became victims because of systematic military action that resulted in the expulsion of the Rohingya ethnic group from the land of Myanmar.

Media's reports stated that since the outbreak of the conflict in the Rakhine region, Indonesia was the first country allowed to enter Myanmar and played an active role in dealing with the humanitarian crisis. The Foreign Minister's statement underscored the diplomacy of the Indonesian government towards its neighbors. Diplomacy is humanitarian in nature to immediately stop victims from being sentenced in the Rohingya region bordering Bangladesh. This humanitarian assistance is coordinated with the Myanmar government which in practice is shunned by the world because it is considered a scapegoat from the Rohingya crisis.

Indonesian humanitarian diplomacy is also part of diplomacy that includes public participation because Indonesian people view the Rohingya problem as part of the problem of Muslims community. Indonesian Foreign Minister Retno explained to Myanmar that public concern was also included in humanitarian diplomacy towards the Rohingya ethnic tragedy.

Retno explained that on 31 August 2017 the Indonesian Humanitarian Alliance for Myanmar (AKIM) had been formed. Members of this alliance are eleven Indonesian humanitarian organizations. The purpose of this alliance is assistance in the fields of education, health, economy and relief. This alliance is said to have committed two million US dollars. Indonesia supports its humanitarian diplomacy by involving NGOs so that it is also conveyed to Myanmar that AKIM is a program that is protected by Indonesia.

The assistance provided for the Rohingya ethnic group reached around 74 tons in the form of food, blankets, water reservoirs, and tents. The Indonesian Ministry of Health also sent aid in the form of a ton of medicines to Rohingya refugees living on the Bangladesh-Myanmar border. Evidence that Indonesia is also cooperating with the public in providing humanitarian assistance is evident from the involvement of the Rapid Action Response and Dompet Dhuafa. In one of its actions ACT sent 2000 tons of rice to the Rohingya refugee area as proof of the importance of NGOs in humanitarian action. In addition to NGOs, Islamic mass organizations 
like Nahdhatul Ulama and Muhammadiyah are also participated in helping Rohingyas in refugee camps.

One of the peaks of humanitarian diplomacy is not only meeting Aung San Suu Kyi who is a central figure after Myanmar's reforms but also the ministers in the president's office, the National Security Advisor and the junior minister of foreign affairs. The meeting with the ministers is part of the continued commitment of Myanmar which needs to be handled technically by several Myanmar ministers.

Foreign Minister Retno said, "when I spoke with Aung San Suu Kyi ... the focus of our attention was the humanitarian crisis in Rakhine. We talked rather long about access to humanitarian assistance to people who really needed it. This humanitarian assistance mission will be led by the Myanmar government and involve the international community, in this case the ICRC and several other countries. Upon the proposal of Indonesia, the Myanmar government welcomed that Indonesia or ASEAN became an important part in the mechanism of providing humanitarian assistance in Rakhine. The assessment regarding what assistance is given, which targets should take precedence will be immediately delivered".

Indonesia has stepped up diplomacy in its humanity so that the great attention of the Indonesian people towards the Rohingya Muslims is channeled and at the same time this public attention is also asking for Myanmar's guarantee to have the same commitment to protect the Rohingya ethnic group which has become an international issue.

Indonesia in conducting humanitarian diplomacy in Myanmar has not neglected aspects of ASEAN regional organizations. Indonesia involved ASEAN in distributing humanitarian aid in Rakhine State on the grounds that Myanmar is a member of ASEAN. Thus, the worsening situation in Rakhine needs to be helped without having to involve themselves in the internal problems of the members.

In more depth, explained Dr. Ryantori from the University of Moestopo (Religious), the benefits gained by Indonesia can be seen at least from two aspects namely the regional and domestic levels. Regionally, Indonesia's position in ASEAN has at least rediscovered its place as a key player, which has recently seemed to be faded. In addition, the controversial policies by several large ASEAN members, such as Malaysia, has added confidence in Indonesia. Domestically, Indonesia's role in assisting the Rohingya plight can at least be a separate lesson given that Indonesia's ethnicity and religion are far more plural than Myanmar. If the Rohingya case can be parsed, it would not be difficult for Indonesia if something like this occurred at home.

The advantage of Indonesia in other words is double, namely at the regional level where Indonesia's credibility is getting stronger because Jakarta is accepted by the Myanmar authorities in submitting its humanitarian proposals. This humanitarian diplomacy benefits Indonesia by enhancing Indonesia's image in the region because of its ability to access Myanmar, which is known to be closed and even able to channel humanitarian assistance which is often rejected except in the case of previous natural disasters. At the domestic level, the Indonesian government is respected by the citizen for being able to actualize the aspirations of Muslims and the public in helping the fate of the Rohingya ethnic, even though it is only temporary. As can be seen in the following discussion, offering a formula that includes implicitly is a step forward but it is not easy to change the tough stance of Myanmar's government policies which are still dominated by the military.

In the perspective of Dr. Ian Montrana from Pertamina University, Indonesia will continue to maintain its informal position as the eldest and biggest brother in Southeast Asia. Indonesia's ability to conduct diplomacy especially with Myanmar which is very closed but capable of being 
breached is evidenced by the high-level meeting of the two countries showing that humanitarian diplomacy also has an impact on diplomacy profile at least in this region.

The role of Indonesia's humanitarian diplomacy towards the Rohingya crisis as described above is based on the foundation of foreign policy creating peace and total humanitarian diplomacy alleviates the suffering of victims in the Rohingya ethnic group while simultaneously preventing further violence from occurring. In this section, it can be said that Indonesian diplomacy, which is humanitarian in nature, is also an arena of diplomacy intelligence because of the opening of the dialogue with the Myanmar government to offer a comprehensive political solution. The format of the political solution that Rohingya in Myanmar and Southeast Asia is wrapped up with a humanitarian approach is helping the Myanmar government in preventing the worsening conditions of refugees and victims of violence and at the same time giving a message to the Myanmar military and Buddhist militant not to continue acts of violence that have even been referred to as genocide.

Indonesia has made humanitarian issues in the state of Rakhine a foothold to propose solutions to ethnic conflicts that have lasted for decades. It is a historical record that discrimination against the Rohingya is at the social political stage so they are not included in Myanmar's political system. Some views say that the Rohingya are not recognized as citizens of Myanmar and are referred to as migrants from Bangladesh. Conversely Bangladesh also does not recognize the Rohingya ethnic group as part of their country.

The existence of Rohingya, which is geographically located in Myanmar, which then became a trigger for conflict starting in 2012 and then exploded even bigger in 2017. The absence of state recognition increases armed resistance from the Rohingya ethnic group which urges its recognition and at a later stage becomes a kind of separatist movement. This military resistance movement made the Rakhine State vulnerable to violence because the guerrilla action provoked a repressive response from the military junta at that time which was then inherited by the current government.

Indonesia's humanitarian diplomacy to Myanmar then also includes proposals submitted directly to the Myanmar government. This Indonesian proposal is known as a $4+1$ formulation for Rakhine submitted to, among others, Aung San Suu Kyi and Armed Forces Commander U Ming Aung Hlaing [16]. Meeting with Suu Kyi, Indonesian Foreign Minister Retno Marsudi presented a comprehensive solution to the conflict in Rakhine. Formula 4+1 consists of (i) restoring stability and security; (ii) maximum restraint and non-violence; (iii) protection of all people residing in Rakhine State, regardless of ethnicity or religion; and (iv) the importance of immediately opening access to humanitarian assistance [17]. Another important element is that the recommendations of the Advisory Commission Report for Rakhine State, led by former Secretary General Kofi Annan, can be implemented immediately.

Submitting this proposal is important in completing the overall case of the Rohingya ethnic group which has not received world attention because of the closure of the Myanmar government. Almost all countries that want to help Myanmar are not openly accepted because they previously criticized the Naypyidaw government's policy towards citizens of Rohingya descent who embraced Islam.

The search for political solutions is not only aimed at Myanmar but also its neighbors who are seen as still unable to be invited to think about the future of this ethnic group. Foreign Minister Retno said that it was important to invite Bangladeshi authorities because they participated in managing the border where the Rohingya were displaced.

Indonesia took a clear stance in the crisis in the Rohingya by stressing that the Myanmar military must provide protection for everyone, especially civilians and more importantly women and children. This message is a reflection of Indonesia's foreign policy in dealing with the 
Rohingya conflict. Human protection is part of human security in the context of international relations. In conflicts where violence occurs, civilians, especially children and women, become the biggest victims because the parties involved in the conflict do not discriminate.

Furthermore, with this humanitarian diplomacy, Indonesia plays a role as a country that cares about regional peace. Dr. Ian Montrana from Pertamina University said, on a praxis level, Indonesia's intervention in Myanmar could strengthen Indonesia's image as a balancer or peace guarantor in the Southeast Asian region - and not the United Nations. With this presence in Myanmar, Indonesia's role in the region indirectly has a good record as a guarantor of peace, something that is needed in creating a calm Southeast Asian environment.

However, the Indonesian formula for Myanmar which can be interpreted as a political and comprehensive solution to the Rohingya case contains several weaknesses. Dr. Ian Montrana explained to a certain extent this humanitarian diplomacy helped deal with the Rohingya ethnic group who experienced violence and expulsion. However, it is also necessary to include Bangladesh which has the most Rohingya ethnicity. Apart from that Bangladesh has cultural similarities with the Rohingya ethnicity.

However, the formula for a comprehensive solution including political issues, explained Dr. Ian Montrana, needs to be watched out for. Indonesia's humanitarian diplomacy in Myanmar can be seen as a form of intervention in domestic affairs. This can be interpreted as a violation of ASEAN's basic principles, namely non-interference. What's more, explained Dr. Ian Montrana, Indonesia still has the issue of separatism in Papua, which will become a backfire if other countries such as the Melanesian Spearhead Group (MSG) or Australia intervene by justifying what Indonesia has done to Myanmar.

\section{Conclusion}

Based on the analysis in the previous part and answering the objectives of the research, several conclusions can be drawn regarding the role of Indonesian humanitarian diplomacy on the Rohingya issue in Myanmar.

First, Indonesia conducted humanitarian diplomacy to deal with the Rohingya ethnic group in Myanmar in the context of implementing the constitutional mandate to maintain world peace and order. The derivative of maintaining peace is also maintaining peace in an area where the ethnic Rohingya minority is facing threats from the Myanmar government which is carrying out acts of expulsion and violence that has caused a humanitarian crisis. With this constitutional basis, Indonesia has an active role in handling the Rohingya issue through humanitarian diplomacy to prevent ethnic conflicts in Myanmar from becoming a source of instability in Southeast Asia. If this instability is left unchecked, it will have an impact on the region, including in Indonesia, which has already been felt by the flood of refugees, which has been accommodated in Aceh.

Secondly, Indonesia's humanitarian diplomacy plays a role in easing the burden on the Rohingya ethnic groups so that there is no continuing violence which has caused hundreds of thousands of people to flee to the Bangladesh border and dozens of people have died. Indonesia took a clear stance that was conveyed to the Myanmar government through its officials that the suffering of the Rohingya ethnic group had to be a priority so that no further violence would be occurred and the military could refrain from excessive acts of violence. The focus on ethnic Rohingya so that international humanitarian assistance can enter the state of Rakhine makes Indonesian diplomacy get a response from the Myanmar government. If other countries focus on Myanmar's central government in resolving the Rohingya issue, Indonesia focused on 
humanitarian assistance that also involves the Indonesian public. With public involvement that views the Rohingya minority as oppressed Muslims, Indonesia can have channeled the aspirations of people who want to help the Rohingya ethnicity.

Third, Indonesia's humanitarian diplomacy towards the Rohingya is also a door to propose a comprehensive political solution in Myanmar. With the formula 4+1, Indonesia actually plays a role as a mediator and promoter of peace in Southeast Asia. Formula 4+1 consists of (i) restoring stability and security; (ii) maximum restraint and non-violence; (iii) protection of all people residing in Rakhine State, regardless of ethnicity or religion; and (iv) the importance of immediately opening access to humanitarian assistance. And additional proposal is the recommendations of the Advisory Commission Report for Rakhine State, led by former Secretary General Kofi Annan, be implemented immediately

Indonesia implicitly wants the protection of minorities in Rakhine as a first step towards ethnic and religious discrimination that is applied to the Rohingya. This message was later conveyed to Myanmar's top leaders even though as previously expected, the Naypyidaw government insisted that this was a domestic problem and would be resolved by the government itself without foreign interference. This hard attitude which then continued from humanitarian diplomacy did not lead to a political solution even though Indonesia was trying to get Myanmar to understand that violence against the Rohingya had tarnished the Southeast Asian region gathered in ASEAN. However, diplomacy that includes a comprehensive solution to the Rohingya issue needs to be careful because there is still the issue of separatism in Papua which can be exploited by foreign parties.

\section{References}

[1] N. Kipgen, “Conflict in Rakhine State in Myanmar: Rohingya Muslims' Conundrum,” J. Muslim Minor. Aff., vol. 33, no. 2, pp. 298-310, 2013.

[2] Tabloid Diplomasi, "Atasi Krisis Rakhine Menlu RI Mengusulkan Formula 4+1," Tabloid Diplomasi, 2018.

[3] F. A. Ardani, F. E. Wahyudi, and H. Susetianingsih, "Kebijakan Indonesia Dalam Membantu Penyelesaian Konflik Antara Etnis Rohingya Dan Etnis Rakhine Di Myanmar (Studi Karakter Kepribadian Susilo Bambang Yudhoyono)," J. Int. Relations, vol. 1, no. 2, pp. 22-28, 2015.

[4] I. Jati, "Comparative Study of the Roles of ASEAN and the Organization of Islamic Cooperation in Responding to the Rohingya Crisis," 2017.

[5] L. A. Alexandra, "Offering support and sharing experiences: Indonesia's approach to peacebuilding," in Rising powers and peacebuilding, Palgrave Macmillan, Cham, 2017, pp. 39 68.

[6] H. Hanai, "KJ Holsti, International Politics-A Framework for Analysis," Int. Relations, vol. 1970, no. 42, pp. $127-131,1970$.

[7] J. N. Rosenau, K. W. Thompson, and G. Boyd, World Politics: An Introduction. Free Pr, 1976.

[8] R. Devetak, J. George, and S. Percy, An introduction to international relations. Cambridge University Press, 2017.

[9] G. R. Berridge, "Economic and Commercial Diplomacy," in Diplomacy, Springer, 2015, pp. 210 224.

[10] A. Holmes and J. S. Rofe, Global Diplomacy. Westview Press, 2016.

[11] C. Lamb, "Humanitarian Diplomacy," IFRC Info, 2008.

[12] P. Régnier, "The emerging concept of humanitarian diplomacy: identification of a community of practice and prospects for international recognition," Int. Rev. Red Cross, vol. 93, no. 884, pp. 1211-1237, 2011.

[13] A. F. Cooper, J. Heine, R. Thakur, and R. C. Thakur, The Oxford handbook of modern diplomacy. Oxford University Press, 2013.

[14] D. Hilhorst, Disaster, conflict and society in crises: everyday politics of crisis response. 
Routledge, 2013.

[15] L. J. Moleong, Metodologi Penelitian Kualitatif. Bandung: PT. Remaja Rosdakarya, 2010.

[16] VOA Indonesia, "Bantu Atasi Krisis Rohingya, Menlu RI Sampaikan Usul '4+1," VOA Indonesia, 2018.

[17] Antara News, "Formula 4+1 dari Indonesia untuk Myanmar demi atasi Krisis Rohingya," Antara News, 2018. 